University of Nebraska - Lincoln

DigitalCommons@University of Nebraska - Lincoln

2009

\title{
Two New Species of Wockia Heinemann (Lepidoptera: Urodidae) from Coastal Dry-Forests in Western Mexico
}

\author{
David Adamski \\ Department of Entomology, National Museum of Natural History, Smithsonian Institution, P.O. Box 37012, \\ MRC 168, Washington, D.C., 20013- 7012, U.S.A., adamskid@si.edu \\ Karina Boege \\ Instituto de Ecologia, Universidad Nacional Autónoma de Mexico, Apartado Postal 70275, Ciudad \\ Universitaria, UNAM 04510, Mexico,D.F., kboege@servidor.unam.mx \\ Jean-Francois Landry \\ Agriculture and Agri-Food Canada, Neatby Building, C.E.F., 960 Carling Avenue, Ottawa, Ontario, K1A 0C6, \\ Canada, landryjf@agr.gc.ca \\ Jae-Cheon Sohn \\ Department of Entomology, University of Maryland, College Park, MD 20742, U.S.A, jsohn@umd.edu
}

Follow this and additional works at: https://digitalcommons.unl.edu/systentomologyusda

Part of the Entomology Commons

Adamski, David; Boege, Karina; Landry, Jean-Francois; and Sohn, Jae-Cheon, "Two New Species of Wockia Heinemann (Lepidoptera: Urodidae) from Coastal Dry-Forests in Western Mexico" (2009). USDA Systematic Entomology Laboratory. 53.

https://digitalcommons.unl.edu/systentomologyusda/53

This Article is brought to you for free and open access by the Entomology Collections, Miscellaneous at DigitalCommons@University of Nebraska - Lincoln. It has been accepted for inclusion in USDA Systematic Entomology Laboratory by an authorized administrator of DigitalCommons@University of Nebraska - Lincoln. 


\title{
TWO NEW SPECIES OF WOCKIA HEINEMANN (LEPIDOPTERA: URODIDAE) FROM COASTAL DRY-FORESTS IN WESTERN MÉXICO
}

\author{
David Adamski, Karina Boege, Jean-François Landry, and Jae-Cheon Sohn
}

(DA) Department of Entomology, National Museum of Natural History, P.O. Box 37012, NHB - E523, Smithsonian Institution, Washington, D.C. 20013-7012, USA (e-mail: david.adamski@ars.usda.gov); (KB) Instituto de Ecología, Universidad Nacional Autónoma de México, Apartado Postal 70-275, Ciudad Universitaria, UNAM 04510, México, D.F. (e-mail: kboege@servidor.unam.mx); (JFL) Agriculture and Agri-Food Canada, Neatby Building, C.E.F., 960 Carling Avenue, Ottawa, Ontario, K1A 0C6, Canada (e-mail: landryjf@agr.gc.ca); (JCS) Department of Entomology, University of Maryland, 4112 Plant Sciences Building, College Park, MD 20742-4454 (e-mail: acontia@hotmail.com)

Abstract.-Two new species of Wockia Heinemann, 1870 (Lepidoptera: Urodidae), $W$. chewbacca and $W$. mexicana, are described from primary dry-forests in western México. A new host record is reported for the genus from larvae of $W$. chewbacca feeding on leaves of Casearia nitida (L.) Jacq. (Salicaceae). Several shared genitalic features and DNA barcode similarities suggest a congeneric relationship between the two Mexican species but uncertain generic placement within Urodidae. Scanning electron micrographs of the larva and illustrations of the larva and pupa of Wockia chewbacca are provided, along with illustrations of male and female genitalia of both Mexican species. Three unusual features found in the larval stage are documented for $W$. chewbacca include; a multi-lobed integument, recurved D2 seta on the shield of T1, and a "hydroid bush" consisting of multiple sensilla trichoidea on the apical turret of the antenna. Locality data indicate the existence of Neotropical elements of Wockia and an expanded distributional range for the genus.

Key Words: Anchimacheta, chaetotaxy, Chamela, DNA barcodes, genitalia, genetic distance, Neotropics, pupa, Spiladarcha, Urodidae, Urodus

Wockia Heinemann, 1870 is a small genus within the Urodidae which, until now contained three named species: $W$. asperipunctella (Bruand 1851) with a Holarctic range, $W$. balikpapanella Kyrki, 1986, from Borneo, and $W$. koreana Sohn, 2008, from Korea. They are relatively small, gray-colored moths with a typical forewing pattern consisting of a narrow, oblique band of raised scales near the basal 1/3. Larvae of $W$.

\footnotetext{
* Accepted by David R. Smith
}

asperipunctella are exposed feeders on leaves of Populus and Salix (Salicaceae) (Brown 1895, Chrétien 1905, Sohn and Adamski 2008). Since the mid 19th century, Wockia was known only from western Europe. However, recent discoveries in northern Asia (Sohn and Adamski 2008), Malyasia (Kyrki 1986), and in North America (Heppner 1997, Landry 1998) have expanded our knowledge of its range. Kyrki (1988) described adult and larval features of Wockia and they include: labial palpi porrect, short, 
with a tuft of scales medially, blunt apically; antenna lamellate in the male, filiform in female; chorda of forewing present; valva deeply divided apically; costal lobe digitate; ovipositor telescopic; antrum wide; ductus bursae short; and larva with AF-group bisetose and adfrontal area with one puncture.

The position of Wockia remains unsettled. Historically, the genus was placed alternatively in Yponomeutidae or Plutellidae (Leraut 1980, Zagulyaev 1989). Kyrki (1988) showed that it lacked defining yponomeutoid features but possessed tortricoid abdominal articulation. He established the family Urodidae to include Wockia along with Urodus Herrich-Schäffer, 1854, and Spiladarcha Meyrick, 1913. The Urodidae seem appropriately placed in the Apoditrysia but their affinities and position remain unresolved (Dugdale et al. 1998).

The purpose of this study is to describe two new species of Wockia recently discovered in the dry deciduous forests of western México, to give some assessment of relationship between the two species by using morphological comparisons and DNA barcode analysis, and to discuss the relationships of these two species with other Urodidae.

\section{Material And Methods}

Herbivory studies of Casearia nitida (L.) Jacq, (Salicaceae) were conducted on sites located at the Estacion de Biología Chamela (EBC), Universidad Nacional Autónoma de México, in Jalisco, México. The station is near the Pacific coast of México $\left(19^{\circ} 30^{\prime} \mathrm{N}, 105^{\circ} 03^{\prime} \mathrm{W}\right)$, has an area of about 3,300 hectares, and is thought to have been undisturbed for hundreds of years because there is no evidence of either natural or anthrogenic fire (Maass and Martinez-Yrizar 2001). The vegetation in this part of the Neotropical Region consists of mainly deciduous plant species intermixed with semi-deciduous species that are primarily distributed along several large streams within the forests (Lott 1987). The annual rainfall averages about $788 \mathrm{~mm}$, and is concentrated but not totally restricted to the months between July and October (Garcia-Oliva et. al. 2002). The mean temperature is about $25^{\circ} \mathrm{C}$, with less than a $5^{\circ} \mathrm{C}$ difference between the warmest and coolest months (Maass and Martinez-Yrizar 2001).

Larvae of Wockia chewbacca were found on leaves of the tropical deciduous tree Casearia nitida (L.) Jacq, (Salicaceae) (Fig. 4). This plant species is distributed throughout the Neotropics from México to South America. C. nitida grows from 2-6 meters in height in the forests that encompasses EBC (Lott 1993). Leaf flush and flowering occurs during the first two weeks of the rainy season (between June and July), and seeds mature between August and September. Adults of Wockia mexicana were collected from a sheet illuminated by blacklight at or near the study sites where larvae of $W$. chewbacca were collected.

For SEM study, larvae and pupae were cleaned in a full-strength solution of allpurpose cleaner, Formula 409 (TM detergent, and subsequently dehydrated in increasing concentrations of alcohol to absolute alcohol. After dehydration, specimens were critical point dried using a Tousimis critical point dryer, mounted on SEM stubs, and coated with gold-palladium $(40 / 60 \%)$, using a Cressington sputter coater. The ultrastructure of the larva and pupa was studied with an Amray 1810 scanning electron microscope at an accelerating voltage of $10 \mathrm{kV}$.

Gross morphological observations and measurements of the larva and pupa were made using a dissecting microscope (reflected light) with a calibrated micrometer. Genitalia were dissected as described by Clarke (1941), except mercurochrome and chlorazol black were used as stains. The Methuen Handbook of 
Colour (Kornerup and Wanscher 1978) was used as a color standard. All types and voucher specimens of immature stages generated from this study are deposited in the National Museum of Natural History, Smithsonian Institution, Washington, D.C. (USNM), and Instituto de Ecología, Universidad Nacional Autónoma de México, Ciudad Universitaria, México, D.F. (UNAM). Authorship for the species described herein is attributed to the senior author. We follow Chase et. al. (2002) for family placement of Caesaria nitida into Salicaceae.

DNA barcode sequences were produced at the University of Guelph, Ontario, Canada. For the DNA barcoding method used, see Hebert et al. (2004) and Hajibabaei et al. (2006). Sequence information was entered in the Barcode of Life Database (BOLD) (www. barcodinglife.org, Ratnasingham and Hebert 2007) along with a photo and collateral information (collecting data) for each specimen. Process numbers given with the sequences cited below refer to sequence numbers in BOLD. Sequences for the new species have been submitted to GenBank with the accession numbers 752230-752256. Genetic distances were analyzed with MEGA4 software (Tamura et al. 2007).

\section{Wockia chewbacca Adamski, new species}

(Figs. 1-3, 5-28)

Diagnosis.-Wockia chewbacca is similar to $W$. mexicana in size and color pattern, however, the former species can be distinguished from the latter by having a slightly more arched costal margin of the forewing, a more linear apical half of the costal lobe of the valva, a smaller saccular lobe of the valva, a vinculum that is not ventrally produced, and a longer aedeagus.

Adult description.-Head: Scales of vertex and frontoclypeus pale brown tipped with white or gray tipped with white; ventral margin of frons white; scape with gray scales tipped with white, flagellum gray; flagellum wider basally in male than in female; outer surface of labial palpus with gray scales tipped with white intermixed with gray scales and few white scales, inner surface usually with more white; proboscis naked.

Thorax: Tegula gray intermixed with few brown scales or with gray scales tipped with white; mesonotum pale brown, or mostly gray except dark gray along anterior margin, or gray intermixed with brown scales; Frontlegs with coxa, trochanter gray, distal $2 / 3$ of femur dark gray intermixed with few dark-gray scales tipped with white, distal margin of tarsomeres with a narrow white band; midleg with coxa, trochanter, and basal $1 / 3$ of femur pale gray, distal $2 / 3$ of femur gray intermixed with gray scales tipped with white, tibia dark gray intermixed with dark-gray scales tipped with white; tarsomeres as above; hindleg with coxa, trochanter, and basal 3/4 of femur pale yellow, distal $1 / 4$ of femur gradually darkening to end; trasomeres as above. Forewing (Fig. 1): length 5.2-6.8 mm (n $=12$ ), gray and pale-gray scales tipped with white and few white scales; basal 1/4 with two brown spots of raised scales, one anterior to $\mathrm{CuP}$ and slightly closer to base than second spot, second spot posterior to $\mathrm{CuP}$; a narrow, oblique band of raised scales near basal 1/3; band dark gray on inner surface, brown on outer surface. Undersurface gray. Hindwing: gray, usually darker than forewing.

Abdomen: Male genitalia (Fig. 2): Uncus conical, setose; gnathos a narrow band, gradually narrowed and curved posteromedialy medially; tegumen rounded; vinculum a narrow band; valva deeply dissected, forming an elongate costal lobe and a shorter, broad, saccular lobe; costal lobe with distal 2/3 setose, gradually widened from base to a rounded apex; saccular lobe with inner 

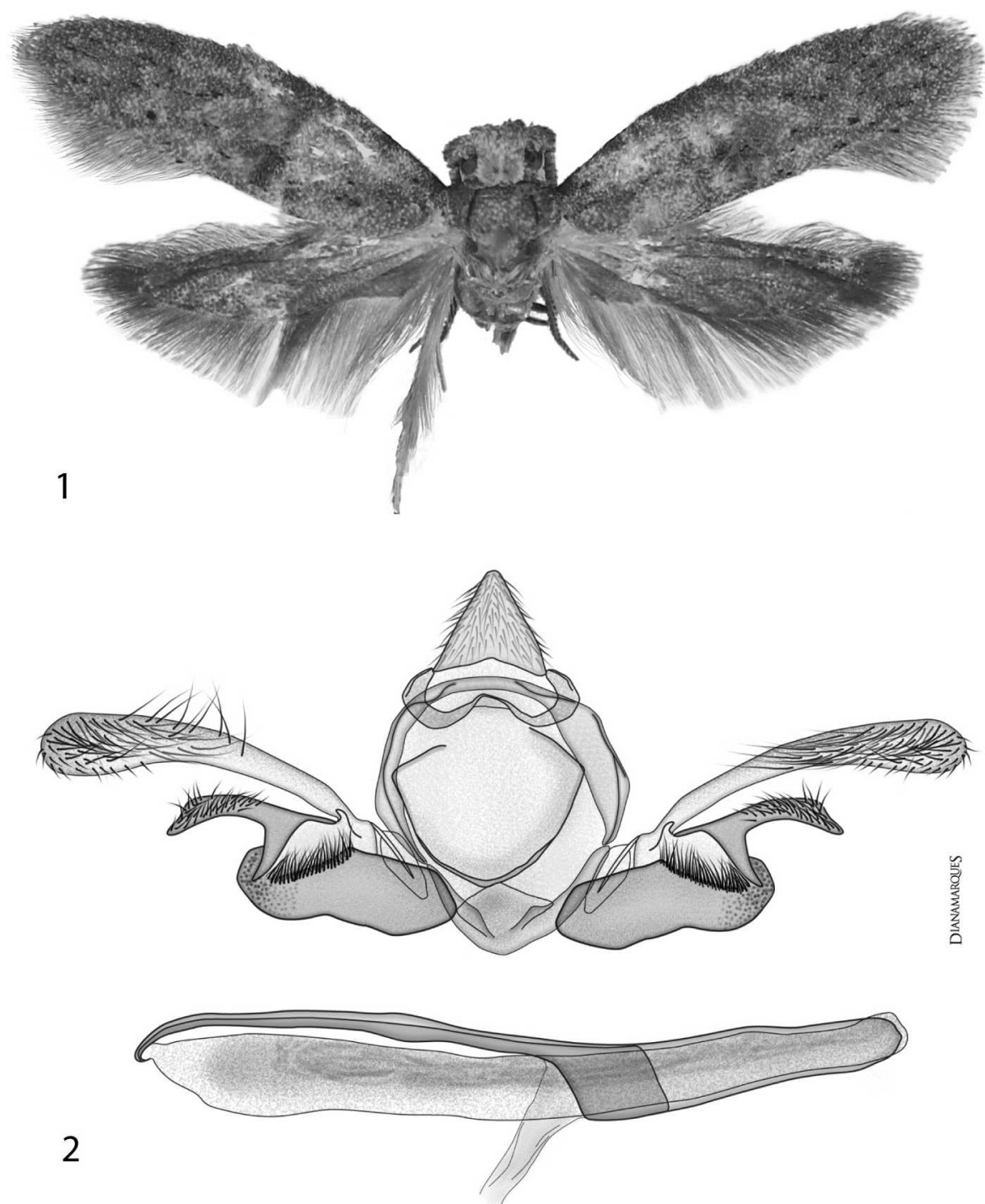

Figs. 1-2. Adult and male genitalia of Wockia chewbacca. 1, Holotype. 2, Genital capsule and aedeagus.

wall curved inwardly with a row of hairlike setae on an inclined distal margin, with an elongate, slightly downcurved, distally setose process; process with a widened bifurcate base; aedeagus elongate, slightly wider at base, gradually narrowed distally, with a narrow supporting rod from base to distal 2/3.

Female genitalia (Fig. 3): Ovipositor elongate, appearing as one membranous part without any telescopic subdivisions from eighth segment to papillae anales; eighth tergum and sternum with setae along distal margin; ostium near posterior end of seventh sternum; antrum wide, gradually narrowed to a point beyond anterior margin of seventh sternum near inception of ductus seminalis; ductus bursae short; corpus bursae elongate; signum, a projection with a slightly serrate edge. 


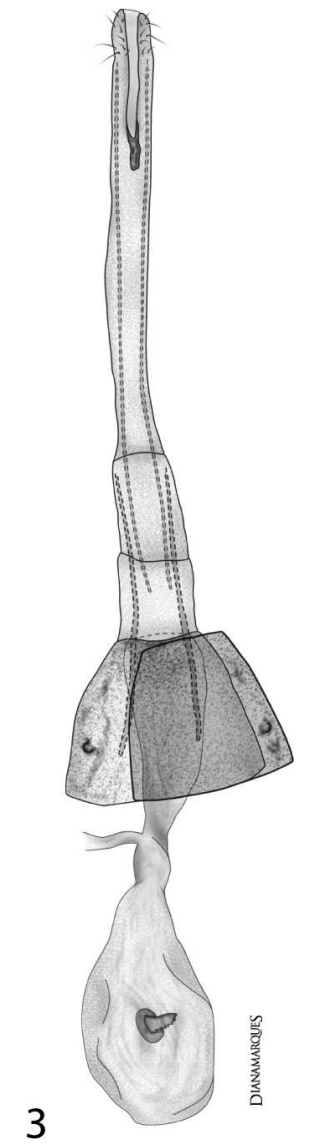

Fig. 3. Female genitalia of Wockia chewbacca.

Larva.-(Figs. 5-24): Length 7.5$8.3 \mathrm{~mm}(\mathrm{n}=6)$. Body pale grayish brown or dark gray, with irregularly patterned brown spots on lateral surface (some field collected specimens are nearly black); body covered with hairlike microtrichiae with widened bases; all pinacula except, V-group pinacula, on apex of fleshy lobes; spiracle on T1 about as large as spiracle on A8, both larger than spiracles on $\mathrm{A} 1-\mathrm{A} 7$.

Head (Figs. 8-15, 24): Hypognathous, epicranial suture long, epicranial notch deep, forming two large, rounded hemispheres; frons and adfrontal sclerites demarcated by an alternating series of short, raised nodules and deep furrows perpendicular to margin; AF-group bisetose, with no puncture on adfrontal sclerite; AF2 at apex of frons, longer than AF1; F1 on basal $1 / 3$ of frons, slightly dorsal to A2; P1 above apex of adfrontal sclerites, ental to A2; P2 dorsolateral to $\mathrm{P} 1$, and slightly lateral to $\mathrm{A} 3 ; \mathrm{C} 1-\mathrm{C} 2$ diagonally situated on smooth area of frons along basal 1/3; A1 in vertical line with $\mathrm{C} 2 ; \mathrm{A} 2$ in line (parallel with adfrontal sclerite) with A1; A3 above antennal base and slightly above A2; L1 dorsolateral to A3; stemmatal pattern with stemma $3-5$ in nearly straight line, stemma 1-2 dorsal lateral to stemma 3, and stemma 6 dorsoposterior to stemma 4; S3 posteroventral to stemma 1; $\mathrm{S} 2$ between and lateral to stemma 2-3; S1 between and lateral to stemma 4-5; SS1 between base of antenna and mandibular condyle; SS2 in straight line with and equidistant to SS1 and SS3; antenna angled posteriolateral from base with apical turret angled more acutely towards posterior direction; sensilla of antenna as in Figs. 12-13, with a "hydroid bush" consisting of multiple sensilla trichoidea on the apical turret; maxillary palpus elongate, flattened dorsoventrally, sensillar arrangement as in Figs 14-15; mandible with 2 subequal setae near condyle, and 6 apical dentitions; retinaculum a narrow, broadly rounded ridge, proximal to and nearly perpendicular with line of dentitions.

Thorax (Figs. 16, 20-21): T1 with Lgroup trisetose, anterior to spiracle; L1 about 2-2 1/2 times longer than L2 and L3, posteroventral to L2; L3 slightly longer and in horizontal line with L2; SV1 about twice length of SV2; V1s approximate, in a line posterior to coxal margins (not shown); shield with two pairs of raised lobes; a dorsolateral lobe bearing SD1, SD2, XD2, and D2, and a dorsomedian lobe bearing XD1 and D1; SD1 about 1/3 longer than XD2 and SD2, slightly posterior to XD2, each seta near top of dorsolateral lobe, D2 with a recurrent apical end, on posterior part of 


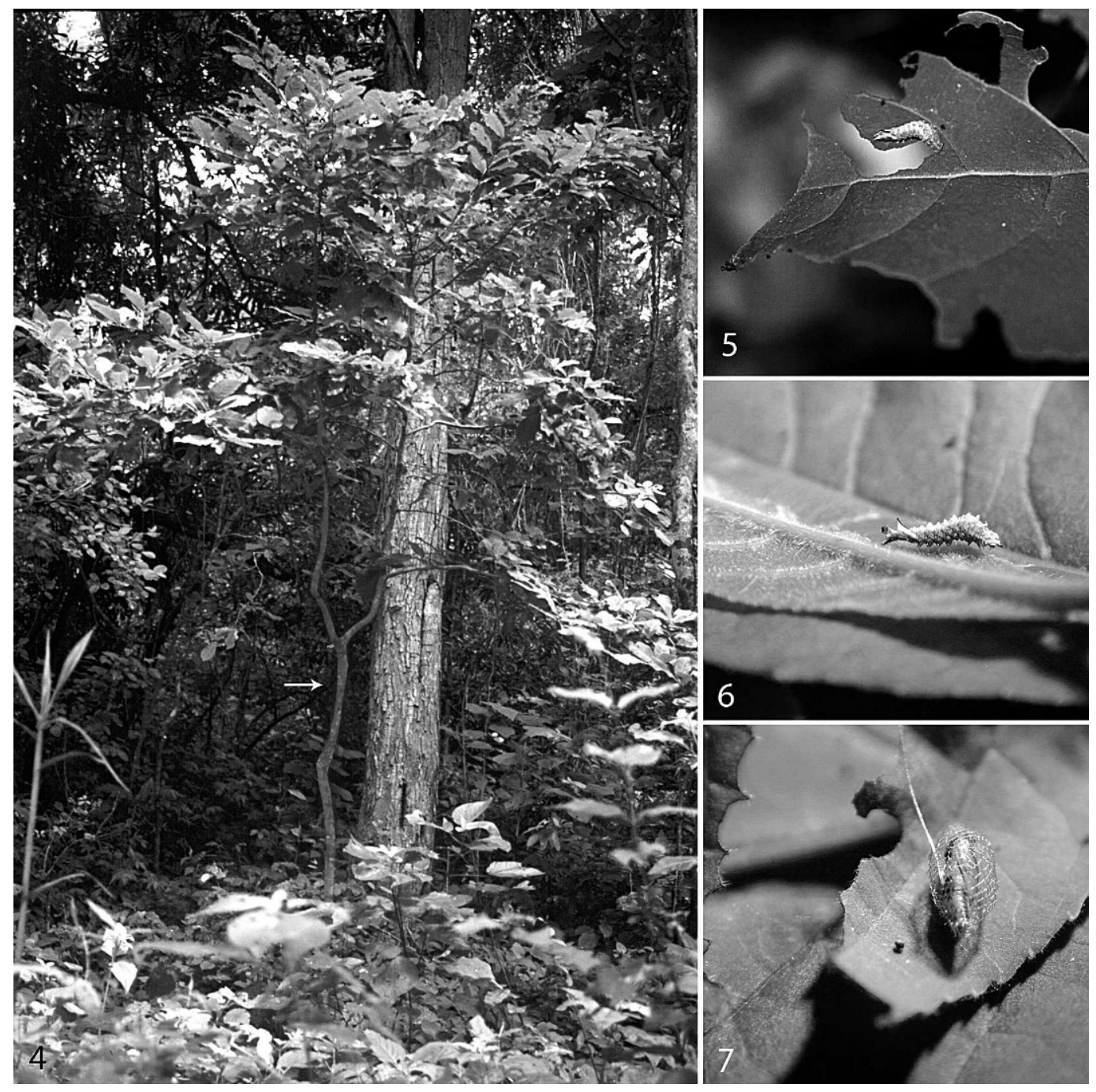

Figs. 4-7. Host plant, Casearia nitida, larva, and pupa within coccon of Wockia chewbacca. 4, Casearia nitida (Salicaceae), note arrow. 5-6, Larva. 7, Pupa within cocoon.

base of lobe, hairlike, about 3 times longer than XD2, SD2, and D1; XD1 about equal in length to D2 but straight, on apical part of dorsomedian lobe; D1 about equal in length to XD2 and SD2, on posterior margin of lobe. T2-T3 (Figs. 16, 20-21): D2 on apex of lobe, about 2 1/2-3 times length of D1; D1 subapical; SD1 on apex of lobe, about 22 1/2 times length of SD2; MD1 and MD2 anteroventral to base of lobe bearing SD-setae; L1 dorsoposterior to L2, about twice length of L2-L3; L3 dorsoposterior to L1, and anterior to, in vertical line with, or slightly posterior to SV1; SV1 pinaculum dark brown; MV1 anteroventral to L2; V1s at least twice distance apart as V1s on T1, slightly farther apart on T2 than on T3 (not shown). Tarsal claw is simple (Fig. 16).

Abdomen (Figs. 18-20, 22-23): A1-A2 with D1 and D2 about equal in lengths; lobe bearing D1 slightly smaller and posterolateral to lobe bearing D2; MD1 anteroventral to lobe bearing D2; SD1 slightly dorsoanterior to or directly 

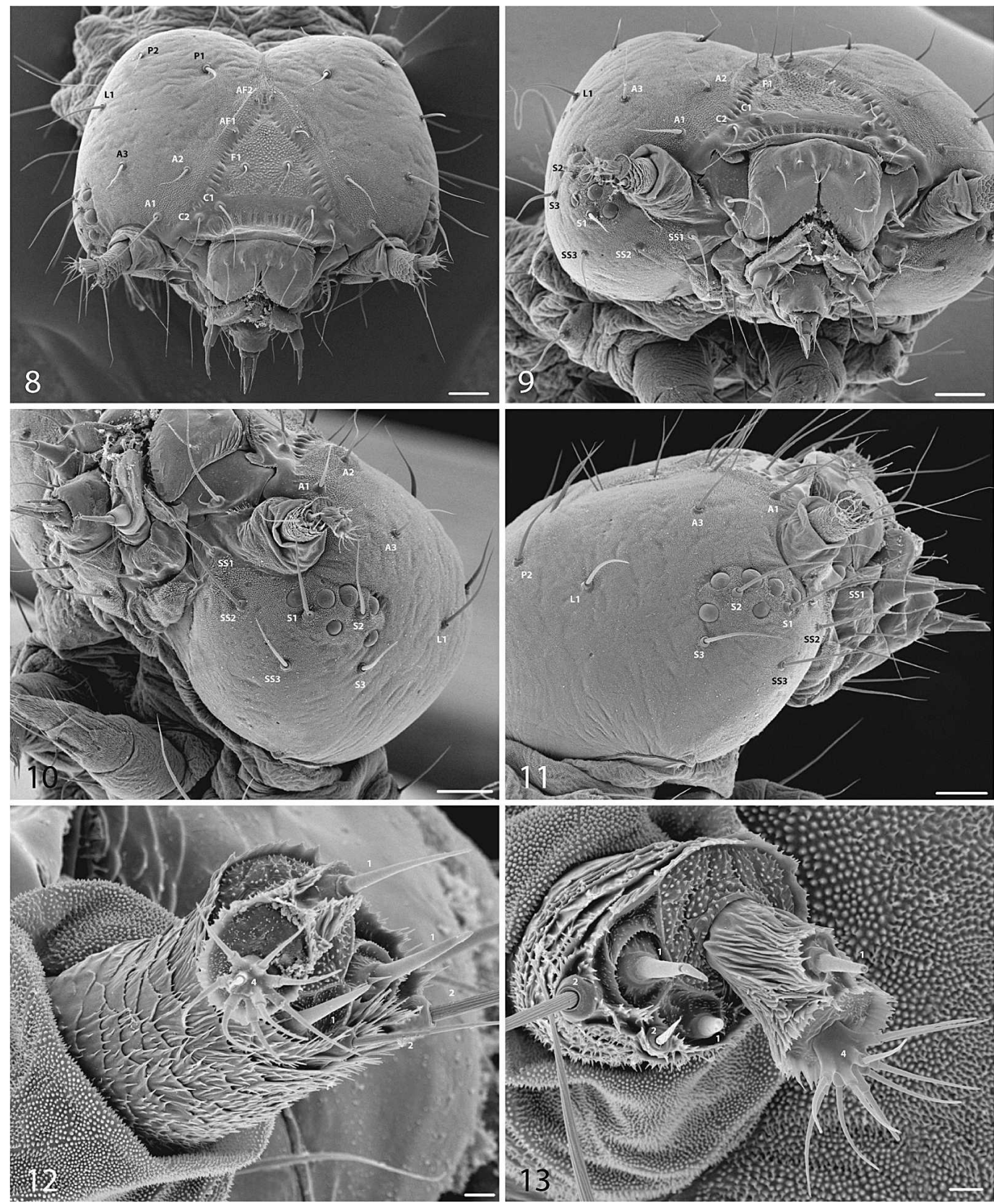

Figs. 8-13. Scanning electron micrographs of head and antenna of Wockia chewbacca. 8, Frontal view. Scale $=100 \mu \mathrm{m}$. 9, Frontal view. Scale $=100 \mu \mathrm{m} .10$, Ventrolateral view. Scale $=100 \mu \mathrm{m} .11$, Lateral view. Scale $=100 \mu \mathrm{m}$. 12, Right antenna (lateral view). $1=$ sensilla basiconica; $2=$ sensilla chaetica; 3 = hydroid "bush" of multiple sensilla trichoidea on the apical turret. Scale $=10 \mu \mathrm{m}$. 13, Right antenna (dorsal view of inner surface). Sensillar nomenclature as above. Scale $=10 \mu \mathrm{m}$.

above spiracle on A1, dorsoanterior to spiracle on A2; SD2 minute, anterior to spiracle; L1 and L2 on same lobe, posterior to spiracle, about equal in lengths; L3 about 1/3 longer than L1L2, slightly posterior to L1 and usually in vertical line with SV1; MV1 anteroventral to $\mathrm{L} 3$; V1s about equidistant as 

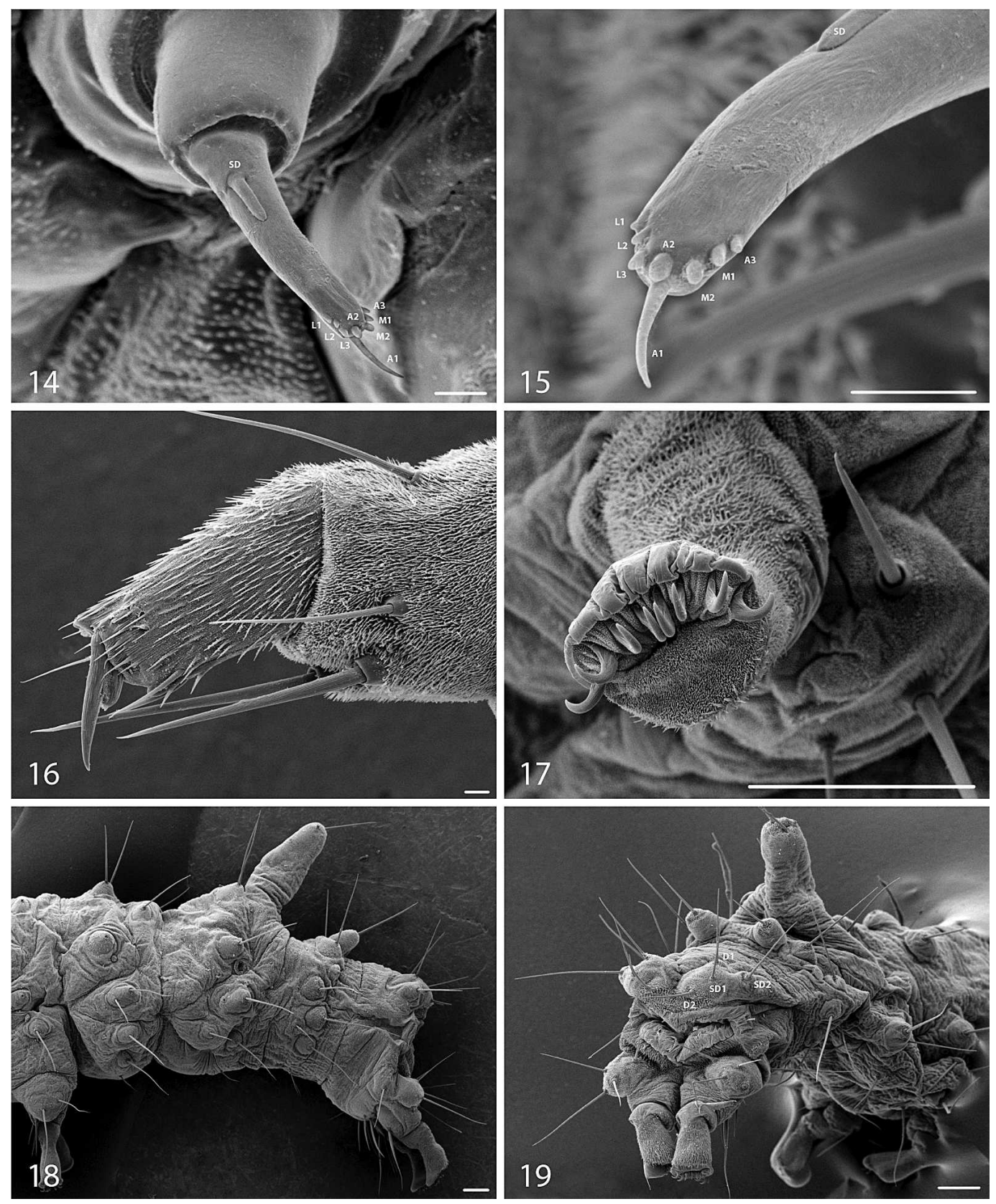

Figs. 14-19. Maxillary palpus, tarsal claw, proleg, and abdomen of Wockia chewbacca. 14, Sensilla of right maxillary palpus (dorsal view). A2 = sensillum styloconicum; A1, A3, M1, M2, L1, L2, and L3 = sensilla basiconica; $\mathrm{SD}=$ sensillum digitiforma. Scale $=10 \mu \mathrm{m}$. 15, Sensilla of right maxillary palpus (dorsoapical view). Sensillar nomenclature as above. Scale $=10 \mu \mathrm{m}$. 16, Left meta thoracic tarsal claw (inner surface). Scale $=10 \mu \mathrm{m} .17$, Left proleg on A1 (ventral view). Scale $=100 \mu \mathrm{m}$. 18, A6-A10 (lateral view). Scale $=100 \mu \mathrm{m} .19$, A6-A10 showing setae on anal plate (posterolateral view). Scale $=100 \mu \mathrm{m}$. 


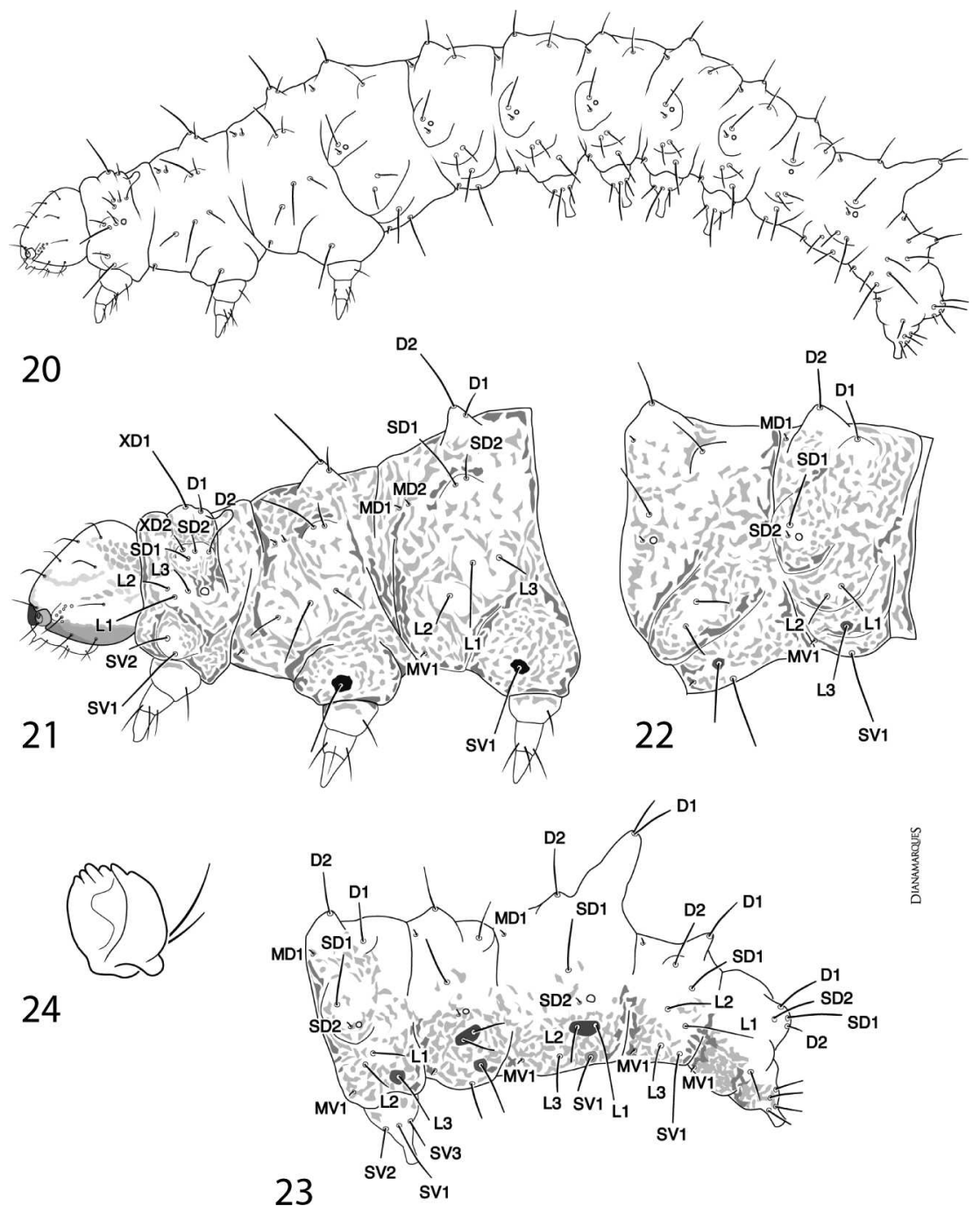

Figs. 20-24. Chaetotaxal maps and mandible of larva of Wockia chewbacca. 20, Entire larva (lateral view). 21, Head and thorax (lateral view). 22, A1-A2 (lateral view). 23, A6-A10 (lateral view). 24, Right mandible (ventral view).

V1s on T1 (not shown); A3-A6 with 4 pairs of narrowly elongate prolegs, crochets uniordinal, in a mesoseries; setae as above except, SD2 anteroventral to spiracle, SV-group trisetose; A7 as above except, SV-group unisetose; A8 with setae as above except; with an elongate lobe on posterior part, bearing both D1 setae, and L3 anterior to all setae; A9 with D1 on apex of lobe, D2 on anterior part of lobe at base; SD1 in near vertical line with D1, L1 and SV1; L3 slightly anterior to all setae; A10 (Figs. 18-20, 23): anal plate with SD1 slightly longer than SD2 and D1, D2 about 1/4 length of SD2 and D1; prolegs extended nearly horizontally, bearing 8-10 uniordinal crochets in an arc.

Pupa (Figs. 25-28).-Length 7.3-9.2 $(\mathrm{n}=2)$. Smooth, pale amber with distinct darker, blotched pattern. Sclerites of maxillae and foreleg fused distally; sclerites of antennae and midlegs parallel from proximal end of sclerite of femur of 

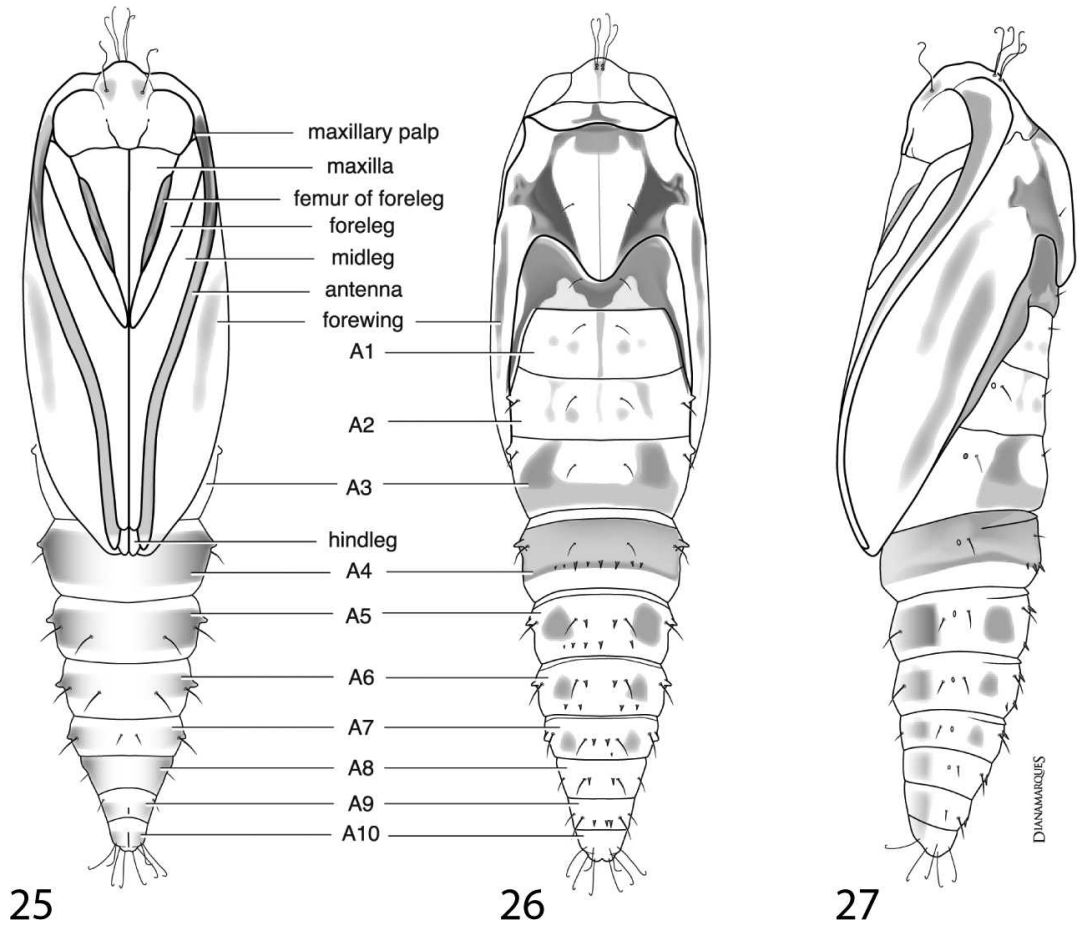

Figs. 25-27. Pupa of Wockia chewbacca. 25, Ventral view. 26, Dorsal view. 27, Lateral view.

foreleg, extending distally, with sclerites of midleg abruptly shortened, exposing the apical part of hindlegs; sclerites of antennae nearly extending to the tips of the forewing. Spiracles protuberant; dorsally protuberant on A4-A9; A4-A10 mobile as unit; a pair of distally hooked setae on upper frons, two pair of such setae on vertex; several pairs of hooked setae on cremaster.

Types.-Holotype, §, "México: Jalisco: Estación de Biologia Chamela, Universidad Nacional Autónomia de México, $19^{\circ} 31^{\prime} \mathrm{N}, 105^{\circ} 03^{\prime} \mathrm{W}, 4-11$ July 2006, r.f. Casearia nitida, Col. Karina Boege"; "USNM \& Genitalia Slide by D. Adamski, No. 83284" [green label]. Deposited in USNM.

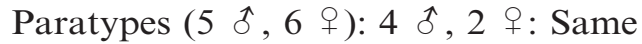
label data as above except, 1 oे, "USNM $\hat{\delta}$ Genitalia Slide by D. Adamski, No. 83286" [green label]; 1 ㅇ, "USNM + Genitalia Slide by D. Adamski, No. 83285" [green label]; 1 oे, "CNC
LEP Database \# 00024615"; "Barcodes of life project, DNA extracted" [blue label]; 1 ઈิ, 1 ㅇ: "Mexico: Jalisco, Chamela Biol. Station, K. Boege, 09 [Sept.] 2002"; "Host plant, Case[a]ria corymbosa $(=$ Casearia nitida), Code: C$3 \mathrm{~N} " ; ~ " R$ [eference] $\mathrm{N}$ [umber] = 41"; "USNM of Genitalia Slide by D. Adamski, No. 83287" [green label], and "R[eference] N[umber] = 45"; "USNM + Genitalia Slide by D. Adamski, No. 83288" [green label]; 3 ㅇ, "Col. Karina Boege, Loc[ation] Chamela, Jal[isco], Mex[ico], Host, Casearia nitida, $\mathrm{R}$ [eference] $\mathrm{N}$ [umber] $=3$, R[eference] $\mathrm{N}$ [umber] $=6, \mathrm{R}$ [eference] $\mathrm{N}$ [umber] $=$ 7, Group 1, 1 Jul[y], 2004, Feeding free on leaves"; "CNCLEP Database \# 00024616"; "Barcodes of life project, DNA extracted" [blue label]. [6 in USNM, 5 in UNAM].

DNA barcode of paratype CNCLEP 00024615 (process \# LNEL187-06) (657 bp): 


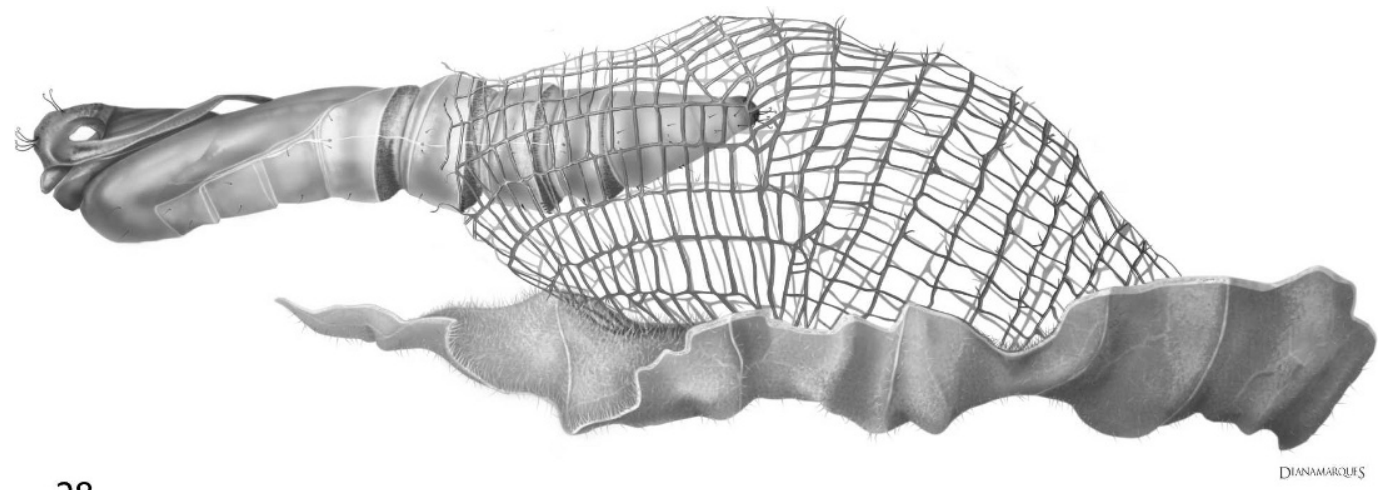

28

Fig. 28. Protuberant pupal exuvium of an emerged adult and cocoon of Wockia chewbacca (lateral view).

AсАтTATAтTтTAтTTTтGGA TTTGAGCAGGAATAATTGGAACT TCTTTAAGTTTATTAATTCGAGC AGAATTAGGTAATCCAGGCTCTT TAATTGGCAGAGATCAAATTTAT AАTACTATTGTTACAGCTCATGC тTтTAтTAтААТтTтTтTтАтАG TTATACСТАTTATAATTGGTGGA TTTGGTAATTGATTAGTTC CTTT AАTACTAGGTGCCCCTGATATAG СTTTCCСTCGTATAAATAАTATA AGATTTTGATTATTAC TC TTTC TTTATTAСТTTTAАTTTСTAGAA GAATTGTAGATAATGGAGCAGGT ACTGGATGAACAGTTTACCCCCC TTTATCTTCСAATATTGCTCATG GAGGTAGTTCTGTTGATTTAGCT ATTTTTтс СтTCACTTAGCTGG TATCTCATCTATTTTAGGAGCCG TAААТTTСАТTТСААСААТТАТT ААТАТАCGACCTATAAAC TАAА TTTСААТСАААТАССССТАТTTG TTTGAGCTGTAGGTATTACAGCT TTACTACTTTTATTATCATTACC TGTTTTAGCTGGAGCAATTACTA TATTATTAACAGATCGAAATTTA ААTAСтTCATTTTTTGACС TGC AGGAGGAGGAGAC CCTATTTTAT ATCAACATTTATTC

Etymology.-The species epithet, chewbacca, is named after the very large and hairy Wookiee character in the Star Wars movie series.
Host and biology.-Larvae of Wockia chewbacca are exposed feeders on leaves of Casearia nitida (L.) Jacq. (Salicaceae) (Figs. 4-6). While feeding, larvae avoid the main and secondary veins of leaves, probably to minimize the ingestion of secondary plant defense chemicals. If disturbed, the larva will wag its body violently from side-to-side until it falls off the leaf, only hanging by a strand of silk from which it uses to climb back to the leaf or branch near the location from which it had fallen. Development from egg to pupa takes about two weeks. The last-instar larva pupates within a finely woven cocoon, which hangs from a branch or leaf from the host tree (Fig. 7). It takes about ten days for the adult to emerge. Emergence takes place from a pupa, which protrudes from its cocoon. The short developmental time allows for multiple generations to occur.

Parasitoids.-Cardiochiles sp. (Hymenoptera: Braconidae).

\section{Wockia mexicana Adamski, new species}

(Figs. 29-30)

Diagnosis.-Wockia mexicana is similar to $W$. chewbacca in size and color pattern, however, the former species can be distinguished from the latter by having a slightly less arched costal margin of the forewing, a lobelike apical half of the costal part of the valva, a larger saccular lobe of the valva, a 

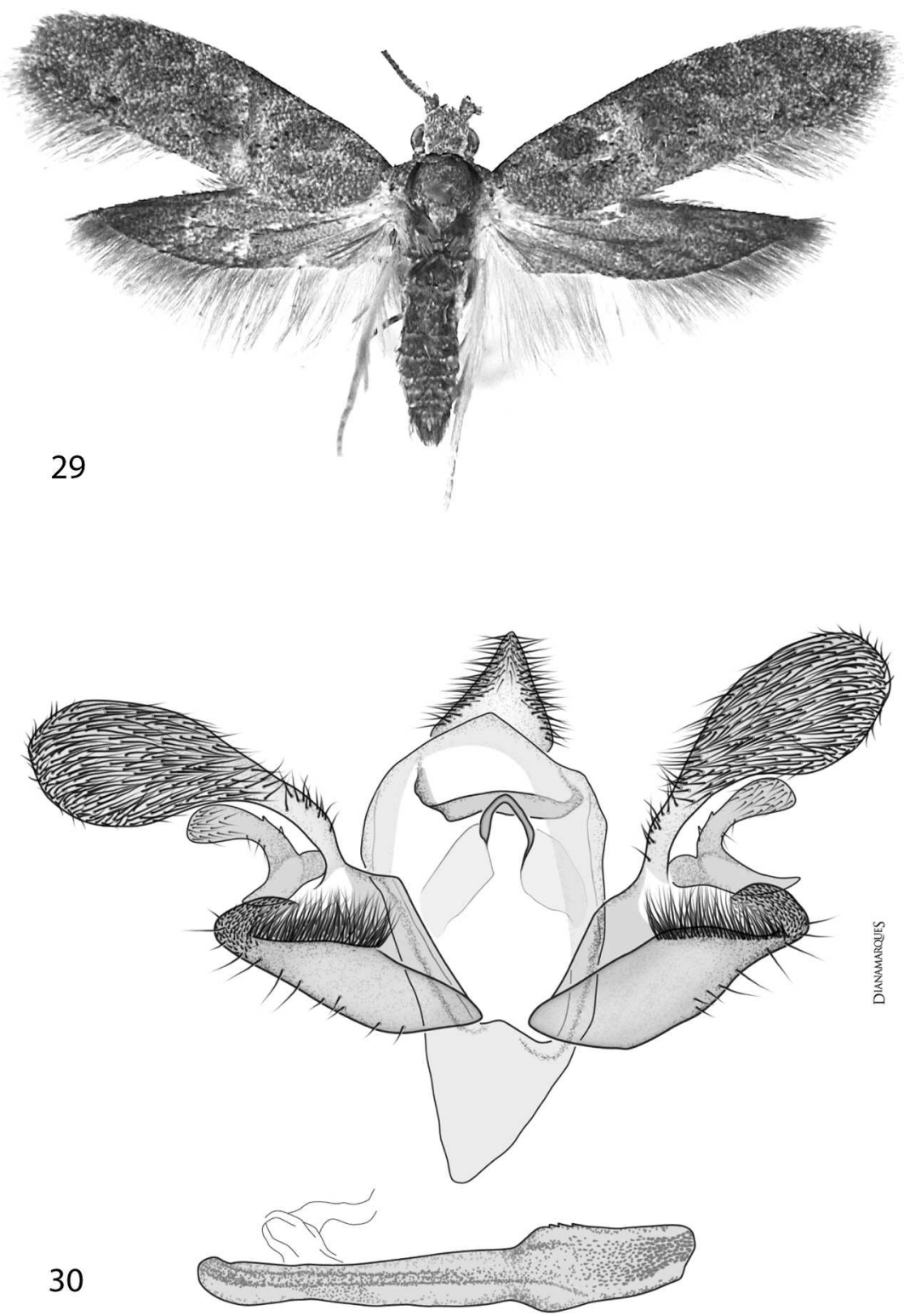

Figs. 29-30. Adult and male genitalia of Wockia mexicana. 29, Holotype. 30, Genital capsule and aedeagus.

ventrally produced vinculum, and a shorter aedeagus.

Adult description.-Head: Scales on vertex and frontoclypeus gray tipped with white; scape with scales gray tipped with white, flagellum gray; inner and outer surfaces of labial palpus dark gray intermixed with dark-gray scales on basal and apical area of all segments; proboscis naked.

Thorax: Tegula and mesonotum with scales gray tipped with white. Legs as in $W$. chewbacca. Forewing (Fig. 29): length $5.6 \mathrm{~mm}(\mathrm{n}=2)$, gray and darkgray scales tipped with white intermixed with dark gray; basal area with two 

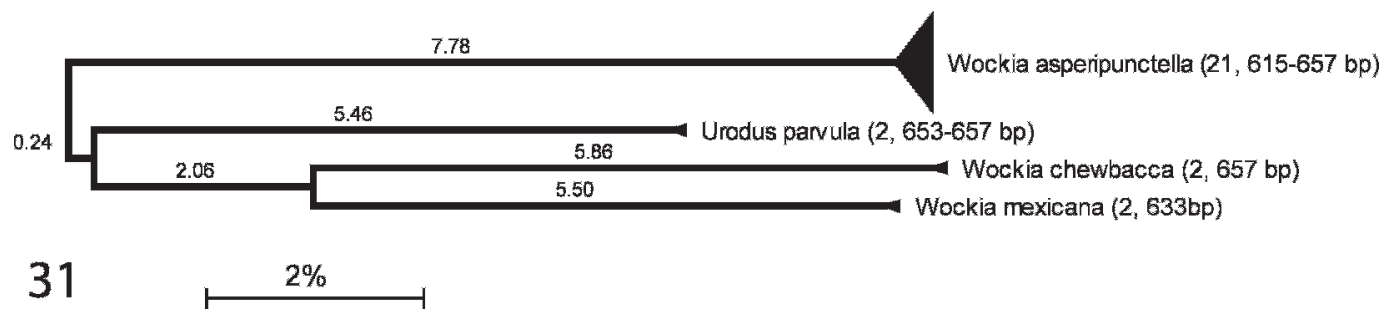

Fig. 31. Neighbor-joining (NJ) tree based on Kimura-2-Parameter (K2P) distances for cytochrome $c$ oxidase I (COI) of 4 species (27 specimens) of Urodidae. Numbers above branches indicate branch length. Numbers in parentheses after species names indicate the number of specimens analyzed and the range of sequence lengths obtained. Individual species branch clusters were collapsed.

brown spots of raised scales, one anterior to $\mathrm{CuP}$ and slightly closer to base than second spot, second spot posterior to $\mathrm{CuP}$; a narrow, oblique, brown band of raised scales near basal 1/3. Undersurface gray. Hindwing: gray, basally translucent, gradually darkening to margin.

Abdomen: Male genitalia (Fig. 30): Uncus conical; gnathos a thin band; transtilla with broad basilateral lobes, each connected by a thin, posteriorlyrounded, median band; tegumen ovoid; vinculum ventrally produced; valva deeply dissected, forming an elongate costal lobe and a shorter, broad, saccular lobe; costal lobe setose, abruptly widened distally from $1 / 4$, forming a broadly rounded ellipsoid; distal saccular lobe with inner wall curved inwardly with a row of hairlike setae on a slightly inclined distal margin, adjacent to a recurved, spinulate, inner wall; saccular lobe with an elongate, acutely curved, distally setose process; process with a widened bifurcate base; aedeagus elongate, abruptly widened on distal $1 / 4$, with an internal rod from base to apex; vesica spiculate, cornuti absent.

Female genitalia: Unknown.

Types.-Holotype, $\hat{\delta}$, "México: Jalisco: Estación de Biologia Chamela, Universidad Nacional Autónomia de México, $19^{\circ} 31^{\prime} \mathrm{N}, 105^{\circ} 03^{\prime} \mathrm{W}, 4-11$ July 2006, Col. D. Adamski, blacklight"; "USNM is Genitalia Slide by D.
Adamski, No. 83231" [green label]; "USNMENT 00656001". Deposited in USNM.

DNA barcode of holotype USNMENT 00656001 (process \# MNAE282-07) (633 $\mathrm{bp)}$ :

АСАTTATATTTTATTTTTGGAA TTTGAGCAGGAATAGTTGGTACT TCCTTTAAGTTTATTAATTCGAG CAGAATTAGGAAATCCTGGATCA TTAATCGGAAGTGATCAAATTTA TAATACTATTGTTACTGCTCATG СТTTTATTATAATTTTTTTTATA GTAATACCTATTATAATTGGAGG ATTTGGTAACTGATTAGTTCCTT TAATATTAGGAGCCCCTGATATA GCTTTCCCCCGTATAAATAACAT AAGATTTTGATTATTACCCCCTT СССТАСТTTTATTAАТTTCATCA AGAATTGTTGACAACGGAGCAGG TACTGGATGAACAGTATACCCAC CСTTATCTTCTAACATTGCTCAT GGAGGAAGATCAGTTGACTTAGC TATTTTCTCCTTACATTTAGCCG GTATTTCATCAATTTTAGGAGCT GTAAATTTTATTTCTACAATTAT TAATATACGACCTATAAATATAT СTTTTAATCAAАTACСТTTATTT GTGTGAGCTGTTGGTATTACAGC TTTACTTCTTTTATTATCCCTTC CTGTCTTAGCTGGAGCTATTACT ATATTATTAACAGATCGAAATTT AAATACTTCATTTTTTGACCCAG CAGGAGGAGGAGAC--------- 
Table 1. Mitochondrial DNA (COI) sequence divergence (\%) among Urodidae species. Uncorrected average pairwise distances are shown for cytochrome oxidase I (COI). There were 590 positions in the final dataset. Shaded cells = mean within-species distances. Cells below diagonal = mean between-species distances. Species abbreviations are as follows: asp, Wockia asperipunctella; che, W. chewbacca; mex, W. mexicana; par, Urodus parvula.

\begin{tabular}{lcrrr}
\hline & par & asp & che & mex \\
\hline Urodus parvula & 0.17 & & & \\
Wockia asperipunctella & 13.88 & 0.37 & & \\
Wockia chewbacca & 13.02 & 16.36 & 0.00 & 0.17 \\
Wockia mexicana & 13.63 & 15.86 & 11.44 & \\
\hline
\end{tabular}

Paratype (1 $\hat{\delta})$ : Same label data as above except, "USNM के Genitalia Slide by D. Adamski, No. 83230" [green label]; "USNMENT 00656000". Deposited in USNM.

Host.-Unknown.

Etymology.-The species epithet, mexicana, is named after the country of collection.

\section{Discussion}

Larval and pupal characters appear to support our placement of Wockia chewbacca into Urodidae. The larva of Wockia chewbacca agrees with autapomorphies for Urodidae given by Dugdale et.al. (1998) including; the prothorax is lacking MXD1, A8 with L3 anteroventral of L1 and L2, with SD1 is moved dorsally almost to the groundplan level of L3. The pupal characters of Wockia asperipunctella, as illustrated by Kyrki (1988) are similar to Wockia chewbacca (Figs. 7, 25-28). They share a meshlike cocoon, sparse abdominal tergal spines, a blotched pattern, and several pairs of apically hooked setae on the frons, vertex, and the cremaster.

Kyrki (1988) states the, "the absence of MXD1 on the prothorax and the single MD seta on the metathorax are good diagnostic characters for the family." Although, we find that larvae of Wockia chewbacca lack the MXD1 seta on the prothorax, it possesses an MDgroup that is bisetose on the metathorax. Without access to the specimens that
Kyrki (1988) examined, it is difficult to say whether Kyrki assessment was accurate, in error, or if the specimens were aberrant in nature.

We provisionally place the Mexican species within Wockia as a "best fit" based on the following apomorphies; adult having transverse band of raised dark scales over the gray ground color of the forewing, hosts within the Salicaceae, and larva with a bisetose AF-group and lacking a puncture on the adfrontal sclerite. There are, however, notable differences in genitalia, as well as pronounced barcode divergence $(>15 \%$, Table 1, Fig. 31) between this pair of species and the type species, Wockia asperipunctella.

A list of features that both Mexican species share include: a narrow, oblique, brown band of raised scales near the basal third of the forewing; a deeply dissected valva (similar to $W$. asperipunctella), forming an elongate costal lobe and a shorter saccular lobe; a row of hairlike setae on a slightly inclined distal margin of the saccular lobe; and an elongate, acutely curved, setose process on the distal part of the saccular lobe. There are, however, significant differences in genitalia: the aedeagus lacks cornuti (present in other Wockia as well as in Urodus; U. parvula examined, genitalia not shown here) and has a long and narrow anterior 'supporting' rod (lacking in other Wockia and U. parvula), the corpus bursae has no lateral accessory 
pouch (present in both $W$. asperipunctella and $U$. parvula), a single signum (two in other Wockia species and Urodus), and the ostium and antrum are wide (very narrow, constricted and recessed in $W$. asperipunctella and $U$. parvula). The overall aspect of their genitalia appears somewhat between $W$. asperipunctella and Urodus. However, there are over 50 species of Urodus in the Neotropics (Heppner 1984); only U. parvula specimens were examined here and incomplete information about a few others was obtained in Clarke (1965). Thus extent of genital character states in that genus was not comprehensively assessed. In addition, we have not assessed the monotypic Spiladarcha Meyrick, 1913 (type species $S$. derelicta Meyrick, 1913 known from a single female from Guyana), another genus also included in the Urodidae by Kyrki (1988), but illustrations provided in Clarke (1965), though not very clear, suggest a closer superficial similarity to Urodus than to the Mexican species of Wockia.

Anchimacheta Walsingham, 1914, with three nominal species all described from Amula, Guerrero, Mexico at high elevation $(>1800 \mathrm{~m}$ ) was synonymized under Spiladarcha by Meyrick (1931) but listed as valid by Heppner (1984). The wing venation as described by Walsingham superficially corresponds to that of Wockia in $A$. capnodes and A. iodes, but there is no mention of hair pencils in the male hindwing and the male genitalia differ by having a shallowly dissected upper and lower part of the valva. Similarly, A. tolmetes illustrated in Walsingham (1914) is quite different from the typical Wockia pattern and lacks the transverse band of raised scales.

Two paratypes of $W$. chewbacca yielded $657 \mathrm{bp}$ sequences that were identical except for one $\mathrm{bp}$ difference $(\mathrm{A} / \mathrm{G})$ at position 627 . The holotype of $W$. chewbacca could not be sequenced at the time. The two $W$. mexicana specimens yielded identical but abbreviated barcode sequences of $633 \mathrm{bp}$, with the last 24 sites (positions 634-657) missing compared to the $W$. chewbacca sequences. The two species differ from each other in DNA barcodes by 65 bp (11.4\%). The amount of genetic divergence among all Urodidae analyzed, which includes three species of Wockia and one species of Urodus, ranges between 11.4 and $16.4 \%$ (Table 1). The two new species cluster closer to $U$. parvula than to $W$. asperipunctella (Fig. 31), probably an effect of long-branch attraction in neighborjoining analysis. More significant, however, is the great amount of genetic distance among all taxa analyzed which suggests that current generic limits are inadequate to accommodate the new species.

The larval features for Wockia chewbacca, multi-lobed integument, recurved D2 seta on the shield of $\mathrm{T} 1$, and the "hydroid bush" of multiple sensilla trichoidea on the apical turret of the antenna, are not known to occur in Lepidoptera. No multi-lobed species of microlepidoptera is illustrated in Stehr (1987), and no larval antenna with multiple sensilla on the apical turret is found in Dethier (1941), or MacKay (1972).

This study also documents a new host record for the genus and an extended distribution into the Neotropics. Given the nondescript aspect of these micromoths we surmise that more species await discovery in the Neotropics.

\section{ACKNOWLEDGMENTS}

We thank Scott Whittaker, Manager, Scanning Electron Microscopy Laboratory, Smithsonian Institution, Washington, DC, USA, for his suggestions on fixation of larvae and the scheduling of scope time; Robert Kula, Systematic Entomology Laboratory, USDA, ARS, Department of Entomology, Smithsonian Institution, Washington, DC, for 
the identifications of the parasitic Hymenoptera; Diana Marques, scientific illustrator, Lisboa, Portugal, for the illustrations of the male and female genitalia, chaetotaxal maps of the larva and pupa, and the preparation of all the plates; Andrea Brauner, Agriculture \& Agri-Food Canada, Ottawa, Canada, Alex Borisenko, Chris Grainger, Paul Hebert, Natalia Ivanova, and Sujeevan Ratnasingham, Biodiversity Institute of Ontario, University of Guelph, Ontario, Canada, who assisted in specimen barcoding and related databasing; Chris Schmit, Canadian Food Inspection Agency, Ottawa, Canada, Jeff Skevington, Agriculture \& Agri-Food, Ottawa, Canada, and Felix Sperling, University of Alberta, Edmonton, Canada, who offered critical comments and suggestions on our analysis of the molecular data; and Steven Passoa, USDA, APHIS, PPQ, Ohio State University, Columbus, Ohio, for his very helpful suggestions in review of the manuscript. Molecular work was supported through funding from the Canadian Barcode of Life Network, Genome Canada, through the Ontario Genomics Institute (NSERC), and from other sponsors listed at www. BOLNET.ca.

\section{Literature Cited}

Brown, R. 1895. [Communication]. Annales de la Société Entomologique de France 63: ccv-ccvi.

Bruand, T. 1851 [1850]. Catalogue systématique et synonymique des Lépidoptères du Département du Doubs. [6]Tinéides. Mémoires de la Société d Emulation de Doubs (1) 3(3): 2358.

Chase, M. W., S. Zmarzty, M. D. Lledo, K. J. Wurdack, S. M. Swensen, and M. F. Fay. 2002. When in doubt put it in Flacourtiaceae: a molecular phylogenetic analysis based on plastid rbcL DNA sequences. Kew Bulletin 57: 141-181.

Chrétien, P. 1905. Le genre Artenacia et les genres des Hyponomeutinae. Le Naturaliste 2(433): 65-67.

Clarke, J. F. G. 1941. The preparation of slides of the genitalia of Lepidoptera. Bulletin of the Brooklyn Entomological Society 36: 149-161.
1965. Catalogue of the type specimens of Microlepidoptera in the British Museum (Natural History) described by Edward Meyrick. Volume 5. Trustees of the British Museum (Natural History), London. 581 pp.

Dethier, V. G. 1941. The antennae of lepidopterous larvae. Bulletin of the Museum of Camparative Zoology 87: 455-507.

Dugdale, J. S., N. P. Kristensen, G. S. Robinson, and M. J. Scoble. 1998. The Smaller Microlepidoptera-Grade Superfamilies, pp. 217-232. In Kristensen, N. P. ed. Lepidoptera, Moths and Butterflies. Volume 1: Evolution, systematics, and biogeography. Handbuch der Zoologie/ Handbook of Zoology, vol. IV, Arthropoda: Insecta, Part 35. N.P. Walter de Gruyter, Berlin and New York.

Garcia-Oliva, F., A. Camou, and J. M. Maass. 2002. El clima de la región central de la costa del pacífico mexicano, pp. 3-10. In Nogúera Aldrete, A. N., J. H. Vega Rivera, A. N. García Aldrete, and M. Quesada Avendaño, eds. Historia natural de Chamela. Instituto de Biología, UNAM, Mexico City.

Hajibabaei, M., D. H. Janzen, J. M. Burns, W. Hallwachs, and P. D. N. Hebert. 2006. DNA barcodes distinguish species of tropical Lepidoptera. Proceedings of the National Academy of Sciences, USA 103: 968-971.

Hebert, P. D. N., E. H. Penton, J. M. Burns, D. H. Janzen, and W. Hallwachs. 2004. Ten species in one: DNA barcoding reveals cryptic species in the Neotropical skipper butterfly Astraptes fulgerator. Proceedings of the National Academy of Sciences of USA 101: 14812-14817.

Heinemann, H. 1870. Die Schmetterlinge Deutschlands und der Schweiz 2(1): 388.

Heppner, J. B. 1984. Atlas of Neotropical Lepidoptera. Checklist: Part 1. Micropterigoidea Immoidea. Dr W. Junk Publishers, The Hague. $112 \mathrm{pp}$.

-1 1997. Wockia asperipunctella in North America (Lepidoptera: Urodidae: Galacticinae). Holarctic Lepidoptera 4(2): 73-74.

Herrich-Schäffer, A. W. 1850-1858. Sammlung neuer oder wenig bekannter aussereuropäischer Schmetterlinge. Vol. 1. 84 pp. $96+24$ pls.

Kyrki, J. 1986. Wockia balikpapanella sp. n. From Borneo (Lepidoptera, Yponomeutidae auct.). Annales Entomologici Fennici (Helsinki) 52: 42-43.

1988. The systematic position of Wockia Heinemann, 1870, and related genera (Lepidoptera: Ditrysia: Yponomeutidae auct.). Nota Lepidopterologica 11(1): 45-69.

Kornerup, A. and J. H. Wanscher. 1978. Methuen Handbook of Colour. 2nd ed. Methuen and Co., Ltd., London. 243 pp. 
Landry, J.-F. 1998. Additional Nearctic records of Wockia asperipunctella, with notes on its distribution and structureal variation (Lepidoptera: Urodidae). Holarctic Lepidoptera 5(1): 9-13.

Leraut, P. 1980. Liste systématique des Lépidoptères de France, Belgique et Corse. Alexanor and Bulletin de la Société Entomologique France, Supplement: 1-334.

Lott, E. J. 1987. Floristic diversity and structure of upland and arroyo forests of coastal Jalisco. Biotropica 19: 228-232.

- 1993. Annotated checklist of the vascular flora of the Chamela bay region. Jalisco Mexico. Occasional Papers of the California Academy of Sciences 148: 160.

Maass, M. and A. Martinez-Yrizar. 2001. NPP Tropical Forest: Chamela, Mexico, 1982-1995. Data set. Available on-line [http://www.daac. ornl.gov] from Oak Ridge National Laboratory Distributed Active Archive Center, Oak Ridge, Tennessee, U.S.A.

MacKay, M. R. 1972. Larval sketches of some Microlepidoptera, chiefly North American. Memoirs of the Entomological Society of Canada 88: 1-83.

Meyrick, E. 1913. Hyponomeutidae, pp. 65-176. In and Meyrick, E. 1913. Exotic Microlepidoptera. Vol. 1 (1912-1916).
1931. Hyponomeutidae, pp. 173-174. In Exotic Microlepidoptera. Vol. 4 (1930-36).

Ratnasingham, S. and P. D. N. Hebert. 2007. BOLD: The Barcode of Life Data Systems (www.barcodinglife.org). Molecular Ecology Notes (OnlineEarly Articles) doi: 10.1111/ j.1471-8286.2007.01678.x.

Stehr, F. W. 1987. Order Lepidoptera, pp. 288-596. In Stehr, F. W. ed. Immature Insects. Kendall/ Hunt Pub. Co., Dubuque, Iowa. xiv +754 pp.

Sohn, J.-C. and D. Adamski. 2008. A new species of Wockia Heinemann, (Lepidoptera: Urodidae) from Korea. Proceedings of the Entomological Society of Washington 110(3): 556-561.

Tamura, K., J. Dudley, M. Nei, and S. Kumar. 2007. MEGA4: Molecular Evolutionary Genetics Analysis (MEGA) software version 4.0. Molecular Biology and Evolution 10.1093/ molbev/msm092.

Walsingham, Lord (Thomas de Grey). 1914. Anchimacheta, pp. 323-324. In Godman, F. D. and O. Salvin, eds. Lepidoptera-Heterocera, 1909-1915, Vol. 4. Tineina, Pterophorina, Orneodina, Pyralidina, and Hepialina, Biologia Centrali Americana. Zoology: Insecta, London. 482 pp., 9 pls.

Zagulyaev, A. K. 1989. Plutellidae, pp. 473-522. In Medvedev, G. S. ed. Keys to the Insects of the European part of the USSR. IV, Part 2. Oxonian Press. 